\title{
SYNTHESIS OF $O$-ALKYL DERIVATIVES OF DEHYDROZINGERONE ANALOGUES
}

\author{
Jovana Muškinja $^{1}$, Zoran Ratković ${ }^{1}$, Branislav Ranković ${ }^{2}$, Marijana Kosanić ${ }^{2}$ \\ ${ }^{1}$ Department of Chemistry, Faculty of Science, University of Kragujevac, \\ ${ }^{2}$ Department of Biology and Ecology, Faculty of Science, University of Kragujevac, \\ Radoja Domanovića 12, 34000 Kragujevac, Republic of Serbia \\ *Corresponding author, E-mail: wor@kg.ac.rs
}

(Received April 11, 2016)

\begin{abstract}
Vanillin and isobuthyl methyl ketone (4-methylpentan-2-one) reacts under Claisen-Schmidt conditions yielding corresponding dehydrozingerone analogue, $(E)-1$ (4-hydroxy-3-methoxyphenyl)-5-methylhex-1-en-3-one. A small series of its $O$-alkyl derivatives was prepared by alkylation of free phenolic group with corresponding alkyl halides. Products had been tested for their biological activity and demonstrated relatively strong in vitro antimicrobial activity towards different strains of bacteria and fungi. All new compounds were well characterized by IR, ${ }^{1} \mathrm{H}$ and ${ }^{13} \mathrm{C}$ NMR spectroscopy and physical data.
\end{abstract}

Keywords: vanillin, dehydrozingerone, enone system, microbiological activity.

\section{INTRODUCTION}

Chalcones, 1,3-diaryl-2-propen-1-ones, are one of the important classes of organic compounds, which have a unique chemical structure with conjugated double bonds and a completely delocalized $\pi$-electron system on both aromatic rings.

Chalcones and its derivatives exhibit different pharmacological and biological activities. They show good antifungal [1-3], antimicrobial [4-6], anticonvulsant [7], antioxidant [8-10], antiprotozoal [11], antitrichomonal [12] antimalarial [13-15], antiinflammatory [16-18], trypsin inhibitors [19] and anti-cancer activity [20-23]. At this kind of molecules is important to identify the fragment of their structure responsible for previously described activities. It has been reported that free phenolic group in ring at position 4- was key factor important for potent antibacterial activity of licochalcone A and licochalcone B [24-25]. Activity is dependant on the nature, position and number of substituent on aromatic rings.

From ginger root, fresh or dried, many different kinds of compounds, such as dehidrozingerone, zingerone, gingerol, shogaol, paradol and their derivatives have been isolated. Vanillin fragment is presented in all kinds of those compounds. Those compounds also have well expressed bioactivity, such as anticancer, anti-oxidant, antimicrobial, antiinflammatory, antidiabetic, anti-allergic [26-28]. 
Starting from this fact we supposed that vanillin is suitable substrate for further transformation, due its easy modification, by $O$-alkylation [29-30], by coupling reactions and forming of divanillin [31], formylations in position 5- [32].

Dehydrozingerone, 4-(4-hydroxy-3-methoxyphenyl)-3-<smiles>COc1cc(/C=C/C(C)=O)ccc1O</smiles>

Figure 1. Structure of dehydrozingerone buten-2-one, Fig. 1, one of pungent constituents of ginger rhizome, also exhibits a wide range of biological activities [3335]. Although conjugate enone system is presented in this phenolic compound, its structure differs from chalcones; instead of the aryl group to the carbonyl is connected the methyl one. Enone system could be easily transformed into some usable heterocyclic derivatives [36-38].

In continuation of our interest in synthesis of vanillin derivatives we synthesized, starting from vanillin, dehydrozingerone analogue (E)-1-(4hydroxy-3-methoxyphenyl)-5-methylhex-1-en-3-one 2a. Starting from this enone compound several $O$-alkyl derivatives were synthesized, and all new products were characterized by their spectral data (IR, ${ }^{1} \mathrm{H}$ NMR and ${ }^{13} \mathrm{C}$ NMR). Their biological activity toward some strains of microorganisms wave been tested.

\section{MATERIALS AND METHODS}

\section{General remarks}

All starting chemicals were commercially available and used as received, except that the solvents were purified by distillation. Chromatographic separations were carried out using silica gel 60 (Merck, 230-400 mesh ASTM) whereas silica gel on Al plates, layer thickness $0.2 \mathrm{~mm}$ (Merck), was used for TLC. IR spectra were recorded on a Perkin-Elmer One FT-IR spectrometer with a $\mathrm{KBr}$ disc, $v$ in $\mathrm{cm}^{-1}$; NMR spectra were recorded on a Varian Gemini 200 MHz spectrometer (200 MHz for ${ }^{1} \mathrm{H}$ and $50 \mathrm{MHz}$ for ${ }^{13} \mathrm{C}$ ), using $\mathrm{CDCl}_{3}$ as solvent and TMS as the internal standard. ${ }^{1} \mathrm{H}$ and ${ }^{13} \mathrm{C}$ NMR chemical shifts were reported in parts per million $(\mathrm{ppm})$ and were referenced to the solvent peak; $\mathrm{CDCl}_{3}\left(7.26 \mathrm{ppm}\right.$ for ${ }^{1} \mathrm{H}$ and $76.90 \mathrm{ppm}$ for ${ }^{13} \mathrm{C}$ ). Multiplicities are represented by s (singlet), $\mathrm{d}$ (doublet), $\mathrm{t}$ (triplet), q (quartet) and $\mathrm{m}$ (multiplet). Coupling constants $(J)$ are in Hertz $(\mathrm{Hz})$.

The antimicrobial activity was estimated by determination of the minimal inhibitory concentration (MIC) using the broth microdilution method against five species of bacteria and five species of fungi.

\section{Experimental procedure}

\section{Chemistry}

Vanillin and 4-methylpentan-2-one reacts under Claisen-Schmidt conditions yielding corresponding enone compound (E)-1-(4-hydroxy-3-methoxyphenyl)-5-methylhex-1-en-3one, 2a in good yield, Scheme 1. Compound 2a was prepared according to slightly modified procedure [39]. A set of its $O$-alkyl derivatives, compounds $\mathbf{2} \mathbf{b}-\mathbf{g}$, was prepared by alkylation of free phenolic group in 2a with corresponding alkyl halides, according to the described literature procedures, [29,30,40], Scheme 2. 
Compounds $\mathbf{2 a}$ and $\mathbf{2 b}$ are known compounds and their chemical synthesis was published earlier [41,42]. Compounds $\mathbf{2 c - g}$ are new compound and their structure and spectral data are given.<smiles>COc1cc(C=O)ccc1O</smiles>

Scheme 1. Synthesis of (E)-1-(4-hydroxy-3-methoxyphenyl)-5-methylhex-1-en-3-one, 2a

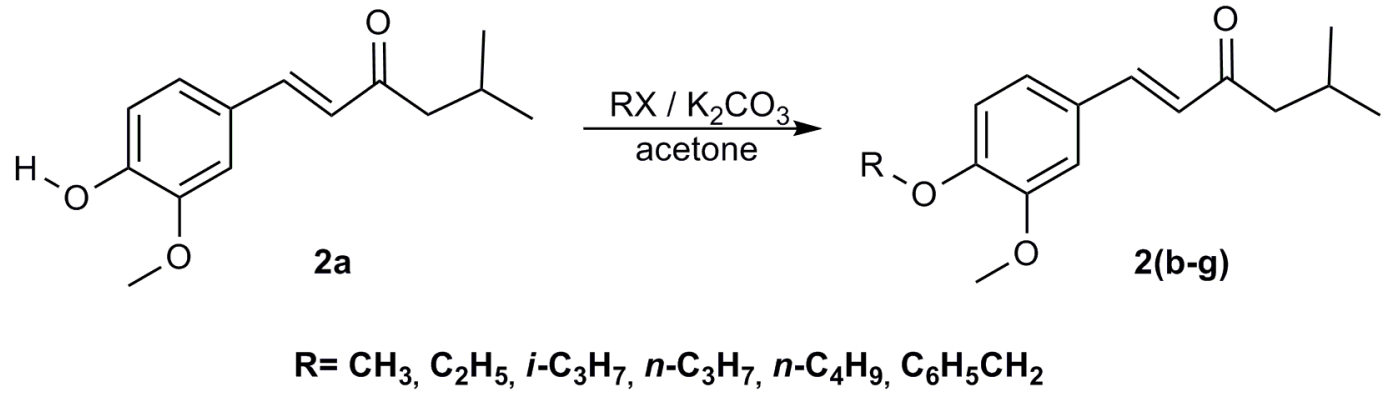

Scheme 2. Synthesis of (E)-1-(4-alkoxy-3-methoxyphenyl)-5-methylhex-1-en-3-one, 2b-g

\section{Chemical synthesis}

\subsection{Synthesis of (E)-1-(4-hydroxy-3-methoxyphenyl)-5-methylhex-1-en-3-one, 2a}

Vanillin, $4.56 \mathrm{~g}(30 \mathrm{mmol})$ was dissolved in $50 \mathrm{~mL}$ of methanol and $100 \mathrm{~mL}$ of $4-$ methylpentan-2-one was added. In to a well stirred homogenous mixture $10 \% \mathrm{NaOH}(25 \mathrm{~mL})$ was added and mixture was stirred for 48 hours at $60^{\circ} \mathrm{C}$. Solvents, methanol and methyl-ibuthyl ketone, was removed under reduced pressure and to oily residue $100 \mathrm{~mL}$ of water was added, then acidified with $2 \mathrm{M} \mathrm{HCl}(\mathrm{pH}=2)$. Product was extracted with $\mathrm{CH}_{2} \mathrm{Cl}_{2}, 3 \times 50 \mathrm{~mL}$, and organic layer was washed with water and dried with anhydrous $\mathrm{Na}_{2} \mathrm{SO}_{4}$. Solvent was distilled off and residue was distilled with steam until no more methyl-i-buthyl ketone odour was presented in distillate. Water/oil residue were extracted with toluene, $3 \times 50 \mathrm{~mL}$, organic phase was dried and solvent was evaporated under reduced pressure, yielding a yellow oily product (E)-1-(4-hydroxy-3-methoxyphenyl)-5-methylhex-1-en-3-one, 2a which crystalize on standing.

Yield: 89.6\%; m.p. $82^{\circ} \mathrm{C}$; IR (KBr): 2970, 2952, 2870, 1678, 1601, 1584, 1517, 1286, 1268, 1146, 1065, $988 \mathrm{~cm}^{-1}$; ${ }^{1} \mathrm{HNMR}\left(\mathrm{CDCl}_{3}\right): 0.98$ (d, $\left.6 \mathrm{H}, J=6.6 \mathrm{~Hz}, 2 \mathrm{xCH}_{3}\right), 2.16-$ $2.30(\mathrm{~m}, 1 \mathrm{H}, \mathrm{CH}), 2.53\left(\mathrm{~d}, 2 \mathrm{H}, J=7.0 \mathrm{~Hz}, \mathrm{CH}_{2}\right), 3.92\left(\mathrm{~s}, 3 \mathrm{H}, \mathrm{OCH}_{3}\right), 6.25(\mathrm{~s}, 1 \mathrm{H}, \mathrm{OH}), 6.61$ (d, 1H, J=16.2Hz, CH), 6.93 (d, 1H, J=8.2Hz, Ar-H), 7.05-7.11 (m, 2H, Ar-H), 7.48 (d, 1H, $J=16.2 \mathrm{~Hz}, \mathrm{CH}) ;{ }^{13} \mathrm{C} \mathrm{NMR}\left(\mathrm{CDCl}_{3}\right): 22.6,25.3,49.6,55.9,109.5,114.8,123.3,124.4,127$, $142.7,146.9,148.2,200.4(\mathrm{CO})$.

2.2. General procedure for synthesis of (E)-1-(4-alkoxy-3-methoxyphenyl)-5methylhex-1-en-3-one, $2 \mathrm{~b}$ - $\mathrm{g}$ 
A mixture of (E)-1-(4-hydroxy-3-methoxyphenyl)-5-methylhex-1-en-3-one, 2a $(0.470$ $\mathrm{g}, 2 \mathrm{mmol}$ ), corresponding alkyl halide (excess, $10 \mathrm{mmol}$ ) and $\mathrm{K}_{2} \mathrm{CO}_{3}(1.94 \mathrm{~g}$, anhydrous, 14 $\mathrm{mmol})$ in acetone $(50 \mathrm{~mL})$ was heated to reflux overnight under argon. Acetone and excess of alkyl halide was evaporated under reduced pressure, solid residue was dissolved in water and extracted with $\mathrm{CH}_{2} \mathrm{Cl}_{2}(3 \times 50 \mathrm{~mL})$. The combined extracts were washed with water and dried over anhydrous $\mathrm{Na}_{2} \mathrm{SO}_{4}$. After removal of the main part of solvent the residue was filtered over short $\mathrm{SiO}_{2}$ column and then distilled with steam, if necessary. Products, compounds 2c and $\mathbf{2 d}$ were isolated as oils, and others crystallize on standing.

\subsubsection{Synthesis of (E)-1-(3,4-dimethoxyphenyl)-5-methylhex-1-en-3-one, $\mathbf{2 b}$}

$\mathrm{CH}_{3} \mathrm{I}, 1.45 \mathrm{~g}$ (excess, $10 \mathrm{mmol}$ ); m.p. $67^{\circ} \mathrm{C}$; Yield: $99.4 \%$.

IR (KBr): 2957, 2926, 2869, 1683, 1648, 1595, 1582, 1517, 1464, 1366, 1273, 1253, 1190, 1141, 1017, $975 \mathrm{~cm}^{-1}$; ${ }^{1} \mathbf{H}$ NMR $\left(\mathrm{CDCl}_{3}\right): 0.98\left(\mathrm{~d}, 6 \mathrm{H}, J=6.6 \mathrm{~Hz}, 2 \mathrm{CH}_{3}\right), 2.17-2.31(\mathrm{~m}$, $1 \mathrm{H}, \mathrm{CH}), 2.53\left(\mathrm{~d}, 2 \mathrm{H}, J=6.8 \mathrm{~Hz}, \mathrm{CH}_{2}\right), 3.92\left(\mathrm{~d}, 6 \mathrm{H}, J=1.2 \mathrm{~Hz}, 2 \mathrm{XOCH}_{3}\right), 6.63(\mathrm{~d}, 1 \mathrm{H}$, $J=16.2 \mathrm{~Hz}, \mathrm{CH}), 6.88(\mathrm{~d}, 1 \mathrm{H}, J=8.2 \mathrm{~Hz}, \operatorname{Ar}-\mathrm{H}), 7.08-7.16(\mathrm{~m}, 2 \mathrm{H}, \operatorname{Ar}-\mathrm{H}), 7.49(\mathrm{~d}, 1 \mathrm{H}$, $J=16.0 \mathrm{~Hz}, \mathrm{CH}) ;{ }^{13} \mathrm{C} \mathbf{N M R}\left(\mathrm{CDCl}_{3}\right): 22.6,25.2,49.6,55.9,109.7,111.1,122.8,124.7,127.5$, $142.3,149.2,151.2,200.1(\mathrm{CO})$.

\subsubsection{Synthesis of (E)-1-(4-ethoxy-3-methoxyphenyl)-5-methylhex-1-en-3-one, 2c}

$\mathrm{C}_{2} \mathrm{H}_{5} \mathrm{I}, 1.56 \mathrm{~g}$ (excess, $10 \mathrm{mmol}$ ); oil; Yield: $80.9 \%$.

IR (KBr): 2957, 2871, 1683, 1649, 1596, 1513, 1466, 1266, 1232, 1141, 1035, 983 $\mathrm{cm}^{-1}$; ${ }^{1} \mathbf{H}$ NMR $\left(\mathrm{CDCl}_{3}\right): 0.98\left(\mathrm{~d}, 6 \mathrm{H}, J=6.6 \mathrm{~Hz}, 2 \mathrm{xCH}_{3}\right), 1.49\left(\mathrm{t}, 3 \mathrm{H}, J=7.0 \mathrm{~Hz}, \mathrm{CH}_{3}\right), 2.17-$ $2.30(\mathrm{~m}, 1 \mathrm{H}, \mathrm{CH}), 2.53\left(\mathrm{~d}, 2 \mathrm{H}, J=7.0 \mathrm{~Hz}, \mathrm{CH}_{2}\right), 3.91\left(\mathrm{~s}, 3 \mathrm{H}, \mathrm{OCH}_{3}\right), 4.14(\mathrm{q}, 2 \mathrm{H}, J=7.0 \mathrm{~Hz}$, $\left.\mathrm{CH}_{2}\right), 6.62(\mathrm{~d}, 1 \mathrm{H}, J=16.2 \mathrm{~Hz}, \mathrm{CH}), 6.86(\mathrm{~d}, 1 \mathrm{H}, J=8.2 \mathrm{~Hz}, \mathrm{Ar}-\mathrm{H}), 7.07-7.14(\mathrm{~m}, 2 \mathrm{H}, \mathrm{Ar}-\mathrm{H})$, $7.49(\mathrm{~d}, 1 \mathrm{H}, J=16.2 \mathrm{~Hz}, \mathrm{CH}) ;{ }^{13} \mathrm{C}$ NMR $\left(\mathrm{CDCl}_{3}\right): 14.6,22.7,25.3,49.7,55.9,64.4,110.1$, $112.3,122.8,124.6,127.3,142.5,149.5,150.7,200.2$ (CO).

\subsubsection{Synthesis of (E)-1-(3-methoxy-4-isopropoxyphenyl)-5-methylhex-1-en-3-one, $2 \mathbf{d}$}

$i-\mathrm{C}_{3} \mathrm{H}_{7} \mathrm{I}, 1.70 \mathrm{~g}$ (excess, $10 \mathrm{mmol}$ ); oil; Yield: $77.7 \%$.

IR (KBr): 2960, 2871, 1682, 1652, 1595, 1509, 1466, 1420, 1268, 1230, 1138, 1110 , $983 \mathrm{~cm}^{-1} ;{ }^{1} \mathbf{H}$ NMR $\left(\mathrm{CDCl}_{3}\right): 0.98\left(\mathrm{~d}, 6 \mathrm{H}, J=6.8 \mathrm{~Hz}, 2 \mathrm{xCH}_{3}\right), 1.39\left(\mathrm{~d}, 6 \mathrm{H}, J=6.0 \mathrm{~Hz}, 2 \mathrm{xCH}_{3}\right)$, 2.17-2.30 (m, 1H, CH), 2.53 (d, $\left.2 \mathrm{H}, J=7.0 \mathrm{~Hz}, \mathrm{CH}_{2}\right), 3.89$ (s, 3H, $\left.\mathrm{OCH}_{3}\right), 4.55-4.67(\mathrm{~m}, 1 \mathrm{H}$, $\mathrm{CH}), 6.62(\mathrm{~d}, 1 \mathrm{H}, J=16.0 \mathrm{~Hz}, \mathrm{CH}), 6.88(\mathrm{~d}, 1 \mathrm{H}, J=8.0 \mathrm{~Hz}, \mathrm{Ar}-\mathrm{H}), 7.09-7.14(\mathrm{~m}, 2 \mathrm{H}, \mathrm{Ar}-\mathrm{H})$, $7.49(\mathrm{~d}, 1 \mathrm{H}, J=16.2 \mathrm{~Hz}, \mathrm{CH}) ;{ }^{13} \mathbf{C}$ NMR $\left(\mathrm{CDCl}_{3}\right): 21.9,22.7,25.3,49.7,55.9,71.3,110.7$, $114.6,122.7,124.6,127.5,142.5,149.8,150.3,200.2(\mathrm{CO})$.

\subsubsection{Synthesis of (E)-1-(3-methoxy-4-propoxyphenyl)-5-methylhex-1-en-3-one, 2e}

$n-\mathrm{C}_{3} \mathrm{H}_{7} \mathrm{Br}, 1.23 \mathrm{~g}$ (excess, $10 \mathrm{mmol}$ ); m.p. $49-50^{\circ} \mathrm{C}$; Yield: $91.7 \%$.

IR (KBr): 2960, 2939, 2874, 1689, 1645, 1619, 1595, 1515, 1466, 1423, 1271, 1226 , 1140, 1033, $973 \mathrm{~cm}^{-1}$; ${ }^{1} \mathbf{H}$ NMR $\left(\mathrm{CDCl}_{3}\right): 0.98\left(\mathrm{~d}, 6 \mathrm{H}, J=6.6 \mathrm{~Hz}, 2 \mathrm{xCH}_{3}\right), 1.05(\mathrm{t}, 3 \mathrm{H}$, $\left.J=7.6 \mathrm{~Hz}, \mathrm{CH}_{3}\right), 1.79-1.98\left(\mathrm{~m}, 2 \mathrm{H}, \mathrm{CH}_{2}\right), 2.17-2.30(\mathrm{~m}, 1 \mathrm{H}, \mathrm{CH}), 2.53\left(\mathrm{~d}, 2 \mathrm{H}, J=6.8 \mathrm{~Hz}, \mathrm{CH}_{2}\right)$, $3.91\left(\mathrm{~s}, 3 \mathrm{H}, \mathrm{OCH}_{3}\right), 4.02\left(\mathrm{t}, 2 \mathrm{H}, J=6.8 \mathrm{~Hz}, \mathrm{CH}_{2}\right), 6.62(\mathrm{~d}, 1 \mathrm{H}, J=16.0 \mathrm{~Hz}, \mathrm{CH}), 6.87(\mathrm{~d}, 1 \mathrm{H}$, $J=8.2 \mathrm{~Hz}, \mathrm{Ar}-\mathrm{H}), 7.07-7.14(\mathrm{~m}, 2 \mathrm{H}, \mathrm{Ar}-\mathrm{H}), 7.49(\mathrm{~d}, 1 \mathrm{H}, J=16.2 \mathrm{~Hz}, \mathrm{CH}) ;{ }^{13} \mathbf{C} \mathbf{N M R}\left(\mathrm{CDCl}_{3}\right)$ : $10.3,22.3,22.7,25.3,49.7,56,70.5,110.3,112.5,122.9,124.6,127.3,142.5,149.6,150.9$, $200.2(\mathrm{CO})$. 


\subsubsection{Synthesis of (E)-1-(4-buthoxy-3-methoxyphenyl)-5-methylhex-1-en-3-one, $\mathbf{2 f}$}

n- $\mathrm{C}_{4} \mathrm{H}_{9} \mathrm{Br}, 1.37 \mathrm{~g}$ (excess, $\left.10 \mathrm{mmol}\right)$; m.p. $54^{\circ} \mathrm{C}$; Yield: $96.5 \%$.

IR (KBr): 2954, 2871, 1651, 1622, 1598, 1514, 1466, 1425, 1273, 1169, 1140, 1042, $981 \mathrm{~cm}^{-1} ;{ }^{1} \mathbf{H}$ NMR $\left(\mathrm{CDCl}_{3}\right): 0.98\left(\mathrm{dt}, 9 \mathrm{H}, J=6.6 \mathrm{~Hz}, 2 \mathrm{xCH}_{3}\right), 1.41-1.59\left(\mathrm{~m}, 2 \mathrm{H}, \mathrm{CH}_{2}\right), 1.77-$ $1.92\left(\mathrm{~m}, 2 \mathrm{H}, \mathrm{CH}_{2}\right), 2.18-2.30(\mathrm{~m}, 1 \mathrm{H}, \mathrm{CH}), 2.53$ (d, $\left.2 \mathrm{H}, J=7.0 \mathrm{~Hz}, \mathrm{CH}_{2}\right), 3.90\left(\mathrm{~s}, 3 \mathrm{H}, \mathrm{OCH}_{3}\right)$, $4.05\left(\mathrm{t}, 2 \mathrm{H}, J=6.8 \mathrm{~Hz}, \mathrm{CH}_{2}\right), 6.62(\mathrm{~d}, 1 \mathrm{H}, J=16.0 \mathrm{~Hz}, \mathrm{CH}), 6.87(\mathrm{~d}, 1 \mathrm{H}, J=8.0 \mathrm{~Hz}, \mathrm{Ar}-\mathrm{H}), 7.07-$ $7.14(\mathrm{~m}, 2 \mathrm{H}, \mathrm{Ar}-\mathrm{H}), 7.49(\mathrm{~d}, 1 \mathrm{H}, J=16.0 \mathrm{~Hz}, \mathrm{CH}) ;{ }^{13} \mathbf{C} \mathbf{~ N M R}\left(\mathrm{CDCl}_{3}\right): 13.8,19.1,22.7,25.3$, $31,49.7,55.9,68.7,110.3,112.4,122.9,124.6,127.3,142.5,149.6,150.9,200.2$ (CO).

\subsubsection{Synthesis of (E)-1-(4-benzyloxy-3-methoxyphenyl)-5-methylhex-1-en-3-one, $\mathbf{2 g}$}

$\mathrm{C}_{6} \mathrm{H}_{5} \mathrm{CH}_{2} \mathrm{Cl}, 1.27 \mathrm{~g}$ (excess, $10 \mathrm{mmol}$ ); m.p. $71-72^{\circ} \mathrm{C}$; Yield: $81.3 \%$.

IR (KBr): 2956, 2930, 2862, 1679, 1646, 1624, 1595, 1512, 1465, 1455, 1256, 1163 , 1138, 1030, $981 \mathrm{~cm}^{-1}$; ${ }^{1} \mathrm{H}$ NMR $\left(\mathrm{CDCl}_{3}\right): 0.97\left(\mathrm{~d}, 6 \mathrm{H}, J=6.6 \mathrm{~Hz}, 2 \mathrm{xCH}_{3}\right), 2.16-2.29(\mathrm{~m}, 1 \mathrm{H}$, $\mathrm{CH}), 2.52\left(\mathrm{~d}, 2 \mathrm{H}, J=6.8 \mathrm{~Hz}, \mathrm{CH}_{2}\right), 3.92\left(\mathrm{~s}, 3 \mathrm{H}, \mathrm{OCH}_{3}\right), 5.18\left(\mathrm{~s}, 2 \mathrm{H}, \mathrm{CH}_{2}\right), 6.61(\mathrm{~d}, 1 \mathrm{H}$, $J=16.2 \mathrm{~Hz}, \mathrm{CH}), 6.87(\mathrm{~d}, 1 \mathrm{H}, J=8.0 \mathrm{~Hz}, \mathrm{Ar}-\mathrm{H}), 7.03-7.09(\mathrm{~m}, 2 \mathrm{H}, \mathrm{Ar}-\mathrm{H}), 7.26-7.51(\mathrm{~m}, 6 \mathrm{H}$, $\mathrm{CH}, \mathrm{Ar}-\mathrm{H}) ;{ }^{13} \mathrm{C}$ NMR $\left(\mathrm{CDCl}_{3}\right): 22.7,25.3,49.7,55.9,70.8,110.4,113.5,122.6,124.8$, $127.1,127.8,127.9,128.5,136.5,142.3,149.8,150.4,200.2$ (CO).

\section{Antimicrobial activity}

\section{Microorganisms and media}

The following bacteria were used as test organisms in this study: Staphylococcus aureus (ATCC 25923), Bacillus subtilis (ATCC 6633), B. cereus (ATCC 10987), Escherichia coli (ATCC 25922) and Pseudomonas aeruginosa (ATCC 27853). All of the bacteria used were obtained from the American Type Culture Collection (ATCC). The bacterial cultures were maintained on Müller-Hinton agar substrates (Torlak, Belgrade). The fungi used as test organisms were: Aspergillus flavus (ATCC 9170), A. fumigatus (ATCC 1022), Candida albicans (ATCC 10259), Penicillium purpurescens (ATCC 48987), P. verucosum (ATCC 48959). All of the fungi were from the American Type Culture Collection (ATCC). The fungal cultures were maintained on potato dextrose (PD) agar, except for $C$. albicans that was maintained on Sabourad dextrose (SD) agar (Torlak, Belgrade). All of the cultures were stored at $4^{\circ} \mathrm{C}$ and subcultured every 15 days.

Bacterial inoculi were obtained from bacterial cultures incubated for $24 \mathrm{~h}$ at $37^{\circ} \mathrm{C}$ on Müller-Hinton agar substrates and brought up by dilution according to the $0.5 \mathrm{McFarland}$ standard to approximately $10^{8} \mathrm{CFU} / \mathrm{mL}$. Suspensions of fungal spores were prepared from freshly mature (3- to 7-day-old) cultures that grew at $30^{\circ} \mathrm{C}$ on a PD agar substrate. The spores were rinsed with sterile distilled water, used to determine turbidity spectrophotometrically at $530 \mathrm{~nm}$, and were then further diluted to approximately $10^{6} \mathrm{CFU} / \mathrm{mL}$ according to the procedure recommended by NCCLS (1998).

\section{Minimal inhibitory concentration (MIC)}

The minimal inhibitory concentration (MIC) was determined by the broth microdilution method using 96-well micro-titer plates [43]. A series of dilutions with 
concentrations ranging from 20 to $0.004 \mathrm{mg} / \mathrm{mL}$ of the tested compounds was used in the experiment against every microorganism tested. The starting solutions of tested compounds was obtained by measuring off a certain quantity of the compounds and dissolving it in 5\% dimethyl sulphoxide (DMSO). Two-fold dilutions of the compounds were prepared in a Müller-Hinton broth for bacterial cultures and a SD broth for fungal cultures. The MIC was determined with resazurin. Resazurin is an redox indicator used for the evaluation of microbial growth. It is a blue non-fluorescent dye that becomes pink and fluorescent when reduced to resorufin by oxidoreductases within viable cells. The boundary dilution without any changing color of resazurin was defined as the MIC for the tested microorganism at a given concentration. As a positive control of growth inhibition, streptomycin and ketoconazole was used. A 5\% DMSO solution was used as a negative control for the influence of the solvents.

\section{RESULTS AND DISCUSSION}

Dehydrozingerone analogues 2a, with $i$-buthyl group attached to carbonyl, were synthesized under Claisen-Schmidt conditions yielding corresponding enone compound $(E)$ 1-(4-hydroxy-3-methoxyphenyl)-5-methylhex-1-en-3-one, 2a in good yield. This compound reacts with various alkyl halides yielding corresponding $O$-alkyl derivatives $\mathbf{2 b - g}$.

Synthesized compounds 2a-g was well characterized by spectral data and microbiological activity. The tested compounds 2a-c demonstrated relatively strong antimicrobial activity inhibiting all tested microorganisms. The MIC for these compounds relative to the tested microorganisms ranged from 0.009 to $5 \mathrm{mg} / \mathrm{mL}$. The strongest antibacterial activity was found in $\mathbf{2 a}$ component, which inhibited all the species of bacteria, especially B. subtilis where measured MIC value was extremely low $(0.009 \mathrm{mg} / \mathrm{mL})$. This compound also inhibited the growth of the tested fungi but in slightly higher concentrations (MIC values were from 0.312 to $0.625 \mathrm{mg} / \mathrm{mL}$ ). Compound $2 \mathrm{~d}$ inhibited only B. subtilis and B. cereus. Other tested components (2e-g) did not inhibite any of the test microorganisms. Among the bacteria, the highest resistance was shown in E. coli, while the most sensitive was B. subtilis. Among the fungi, the most sensitive appeared to be $C$. albicans.

The antimicrobial activity was compared with the standard antibiotics, streptomycin (for bacteria) and ketoconazole (for fungi). The results showed that standard antibiotics had stronger activity than tested samples as shown in Table 1. In these experiments, the compounds examined at the same concentrations showed a slightly stronger antibacterial than antifungal activity. These results could be expected due to the fact that numerous tests proved that bacteria are more sensitive to the antibiotic compared to fungi [44]. The reason for different sensitivities between fungi and bacteria can be found in different permeabilities of the cell wall. The cell wall of the gram-positive bacteria consists of peptidoglycans (murein) and teichoic acids, while the cell wall of gram-negative bacteria consists of lipopolysaccharides and lipopoliproteins [45], whereas, the cell wall of fungi consists of polysaccharides such as chitin and glucan [46].

Compounds 2b-c have substituent with short carbon chain on oxygen ( $\mathrm{Me}$ and $\mathrm{Et}$ ), whereas compounds $\mathbf{2 d - g}$ have longer carbon chain on oxygen $(i$ - $\operatorname{Pr}, n-\operatorname{Pr}, n$-Bu and Bz). We suppose that structure of alkyl group is responsible for the lack of their activity.

From this point, the results of this study suggest that dehydrozingerone analogue derivatives 2a-g are promising candidates, after some modification, for testing of some other activities. 


\section{References:}

[1] BAG, S., RAmar, S., Degani, M.S. (2009): Synthesis and biological evaluation of $\alpha, \beta$ unsaturated ketone as potential antifungal agents, Med. Chem. Res. 18: 309-316.

[2] Lahtchev, K.L., Batovska, D.I., Parushev, S.P., Ubiyvovk, V.M., SibiRny, A.A. (2008): Antifungal activity of chalcones: a mechanistic study using various yeast strains, Eur. J. Med. Chem. 43: 2220-2228.

[3] Mostahar, S., Katun, P., Islam, A. (2007): Synthesis of two vanillin ring containing flavones by different methods and studies of their antibacterial and antifungal activities, J. Biol. Sci. 7: 514-519.

[4] Yayli, N., Ucuncu, O., Yasar, A., Kucuk, M., Akyuz, E, Karaoglu, S.A. (2006): Synthesis and biological activities of $N$-alkyl derivatives of $o-, m-$, and $p$-nitro $(E)-4-$ azachalcones and stereoselective photochemistry in solution with theoretical calculations, Turk. J. Chem. 30: 505-514.

[5] Trivedi, A.R., DodiYA, D.K., Ravat, N.R., Shah, V.H. (2008): Synthesis and biological evaluation of some new pyrimidines via a novel chalcone series, Arkivoc (xi): 131-141.

[6] Opletalova, V. (2000): Chalcones and their heterocyclic analogs as potential therapeutic agents in bacterial diseases, Cesk. Slov. Farm. 49: 278-284.

[7] KAUSHIK, S., Kumar, N., Drabu, S. (2010): Synthesis and anticonvulsant activities of phenoxychalcones, Pharm. Res. 3: 257-262.

[8] Vasil'ev, R.F., Kancheva, V.D., Fedorova, G.F., Batovska, D.I., Trofimov, A.V. (2010): Antioxidant activity of chalcones: The chemiluminescence determination of the reactivity and the quantum chemical calculation of the energies and structures of reagents and intermediates, Kinet. Katal. 51: 507-515.

[9] Sivakumar, P.M., Prabhakar, P.K., Doble, M. (2010): Synthesis, antioxidant evaluation and quantitative structure activity relationship studies of chalcones, Med. Chem. Res. 19: 1-17.

[10] Vogel, S., Ohmayer, S., Brunner, G., Heilmann, J. (2008): Natural and non-natural prenylated chalcones: Synthesis, cytotoxicity and antioxidative activity, Bioorg. Med. Chem. 16: 4286-4293.

[11] Lunardi, F., Guzela, M., Rodrigues, A.T., Corre, R., Eger-Mangrich, I., Steindel, M., Grisard, E.C., Assreuy, J., Calixto, J.B., Santos, A.R.S. (2003): Trypanocidal and leishmanicidal properties of substitution-containing chalcones, Antimicrob. Agents Chemother. 47: 1449-1451.

[12] Oyedapo, A.O., Mankanju, V.O., Adewunmi, C.O., Iwalewa, E.O., Adenowo, T.K., (2004): Antitrichomonal activity of 1,3-diaryl-2-propen-1-ones on Trichomonas gallinae, Afr. J. Trad. CAM 1: 55-62

[13] MotTA, L.F., Gaudio, A.C., TAKahatA, Y. (2006): Quantitative structure-activity relationships of a series of chalcone derivatives (1,3-diphenyl-2-propen-1-one) as anti plasmodium falciparum agents (anti malaria agents), internet electron. J. Mol. Des. 5: 555-569.

[14] Awasthi, S.K., Mishra, N., Kumar, B., Sharma, M., Bhattacharya, A., Mishra, L.C., BHAsIN, V.K. (2009): Potent antimalarial activity of newly synthesized substituted chalcone analogs in vitro, Med. Chem. Res. 18: 407-420.

[15] LIM, S.S., KIM, H.S., LEE, D.U. (2007): In vitro antimalarial activity of flavonoids and chalcones, Bull. Korean Chem. Soc. 28: 2495-2497. 
[16] Zhang, X.W., ZhaO, D.H., Quan, Y.C., Sun, L.P., Yin, X.M., Guan, L.P. (2010): Synthesis and evaluation of anti-inflammatory activity of substituted chalcone derivatives, Med. Chem. Res. 19: 403-412.

[17] Herencia, F., Ferrandiz, M.L., Ubeda, A., Dominguez, J.N., Charris, E.J., Lobo, G.M., AlcaraZ, M.J. (1998): Synthesis and anti-inflammatory activity of chalcone derivatives, Bioorg. Med. Chem. Lett. 8: 1169-1174.

[18] NowAKOWSKA, Z. (2007): A review of anti-infective and anti-inflammatory chalcones Eur. J. Med. Chem. 42: 125-137.

[19] Maliar, T., JedinaK, A., Kadrabova, J., Sturdik, E. (2004): Structural aspects of flavonoids as trypsin inhibitors, Eur. J. Med. Chem. 39: 241-248.

[20] Romagnoli, R., Baraldi, P.G., Carrion, M.D., Cara, C.L., Cruz-Lopez, O., Preti, D. (2008): Design, synthesis, and biological evaluation of thiophene analogues of chalcones, Bioorg. Med. Chem. 16: 5367-5376.

[21] Echeverria, C., Santibanez, J.F., Donoso-Tauda, O., Escobar, C.A., Tagle, R.R. (2009): Structural antitumoral activity relationships of synthetic chalcones, Int. J. Mole. Sci. 10: 221-231.

[22] Szliszka, E., Czuba, Z.P., Mazur, B., Sedek, L., Paradysz, A., Krol, W. (2009): Chalcones enhance TRAIL-induced apoptosis in prostate cancer cells, Int. J. Mol. Sci. 11: $1-13$

[23] Ilango, K., Valentina, P., Saluja, G. (2010): Synthesis and in vitro anticancer activity of some substituted chalcones derivatives, Res. J. Pharm. Biol. Chem. Sci. 1: 354-359.

[24] Tsukiyama, R.I., Katsura, H., TokURiki, N., Kobayashi, M. (2002): Antibacterial activity of licochalcone A against spore-forming bacteria, Antimicrob. Agents Chemother. 46: 1226-1230.

[25] Chen, M., Christensen, S.B., Zhai, L., Rasmussen, M.H., Theander, T., Frokjaer, S., Steffansen, B., Davidsen, J., Kharazmi, A. (1997): The novel oxygenated chalcone, 2,4-dimethoxy-4'-butoxychalcone, exhibits potent activity against human malaria parasite Plasmodium falciparum in vitro and rodent parasites Plasmodium berghei and Plasmodium yoelii in vivo, J. Infect. Dis. 176: 1327-1333.

[26] Semwal, R.B., Semwal, D.K., CombrincK, S., Viljoen, A.M. (2015): Gingerols and shogaols: Important nutraceutical principles from ginger, Phytochemistry 117: 554-568.

[27] NAKAmURA, H., YAmAmOTO, T. (1983): The active part of the [6]-gingerol molecule in mutagenesis, Mutat. Res. Lett. 122: 87-94.

[28] Dugasani, S., Pichika, M.R., Nadarajah, V.D., BalijePalli, M.K., Tandra, S., KorlaKUNTA, J.N. (2010): Comparative antioxidant and anti-inflammatory effects of [6]-gingerol, [8]-gingerol, [10]-gingerol and [6]-shogaol, J. Ethnopharmacol. 127: 515520.

[29] KATRITZKy, A.R., Long, Q., He, H., QIUA, G., WilcoX, A.L. (2006): Preparation of 2alkoxy-5-methoxybenzaldehydes and 2-ethoxy-5-alkoxybenzaldehydes, Arkivoc (vi): 868-875.

[30] Tatsuzaki, J., Bastow, K.F., Nakagawa-Goto, K., Nakamura, S., Itokawa, H., LEE, K. (2006): Dehydrozingerone, chalcone, and isoeugenol analogues as in vitro anticancer agents, J. Nat. Prod. 69: 1445-1449.

[31] Nishimura, R.T., Giammanco, C.H., Vosburg, D.A. (2010): Green, enzymatic syntheses of divanillin and diapocynin for the organic, biochemistry, or advanced general chemistry laboratory, J. Chem. Ed. 87: 526-527.

[32] Blažević, N., Kolbah, D., Belin, B., Šunjić, V., Kajfež, F. (1979): Hexamethylenetetraamine, a versatile reagent in organic syntheses, Synthesis 3: 161-176. 
[33] Motohashi, N., Yamagami, C., Tokuda, H., Konoshima, T., OKUdA, Y., OKuda, M., MukainaKA, T., NishinO, H., SAITO, Y. (1998): Inhibitory effects of dehydrozingerone and related compounds on 12-O-tetradecanoylphorbol-13-acetate induced Epstein-Barr virus early antigen activation, Cancer Lett. 134: 37-42.

[34] Adams, B.K., Ferstl, E.M., Davis, M.C., Herold, M., KurtKaya, S., Camalier, R.F., Hollingshead, M.G., Kaur, G., SAusville, E.A., Rickles, F.R., SNYDER, J.P., LiotTA, D.C., SHOJI, M. (2004): Synthesis and biological evaluation of novel curcumin analogs as anti-cancer and anti-angiogenesis agents, Bioorg. Med. Chem. 12: 38713883.

[35] Ishida, J., Ohtsu, H., Tachibana, Y., Nakanishi, Y., Bastow, K.F., Nagai, M., Wang, H.K., ItoKawA, H., LeE, K.H. (2002): Antitumor agents. Part 214: synthesis and evaluation of curcumin analogues as cytotoxic agents, Bioorg. Med. Chem. 10: 3481-3487.

[36] Abdel-Rahman, A.A.H., Abdel-Megied, A.E.S., Hawata, M.A.M., Kasem, E.R., SHABAAN, M.T. (2007): Synthesis and antimicrobial evaluation of some chalcones and their derived pyrazoles, pyrazolines, isoxazolines, and 5,6-dihydropyrimidine-2-(1H)thiones, Monatshefte 138: 889-897.

[37] Kalirajan, R., Sivakumar, S.U., Jubie, S., Gowramma, B., Suresh, B. (2009): Synthesis and biological evaluation of some heterocyclic derivatives of chalcones, Int. J. ChemTech. Res. 1: 27-34.

[38] Ratković, Z., Muškinja, J., BurmudžIJa, A., Ranković, B., Kosanić, M., Bogdanović, G.A., Simović Marković, B., Nikolić, A., Arsenijević, N., ĐorĐević, S., VuKIĆEVIĆ, R.D. (2016): Dehydrozingerone based 1-acetyl-5-aryl-4,5-dihydro-1Hpyrazoles: synthesis, characterization and anticancer activity, J. Mol. Struct. 1109: 8288.

[39] SMITH, L.R., (1996): Rheosmin ("Raspberry Ketone") and Zingerone, and their preparation by crossed aldol-catalytic hydrogenation sequences, Chem. Educator 1: 118.

[40] LoEv, B., DAwson, C.R. (1956): Alkylphenols related to the poison ivy principle. An improved method of synthesis involving the Na-Butanol cleavage of benzyl ethers, $J$. Am. Chem. Soc. 78: 6095-6101.

[41] Suri, K.A., Sood, R.P., Suri, O.P., Atal, C.K., Singh, G.B. (1981): Synthesis of potential anti-inflammatory compounds, Indian J. Pharm. Sci. 43: 226-228.

[42] Nomura, H., HotTA, S. (1925): Synthesis of the homologs of zingerone, Sci. Reports Tohoku Imperial University, Series 4: Biology, 14: 131-142

[43] SARKer, S.D., NAhar, L., Kumarasamy, Y. (2007): Microtitre plate-based antibacterial assay incorporating resazurin as an indicator of cell growth, and its application in the in vitro antibacterial screening of phytochemicals, Methods 42: 321324.

[44] Hugo, W.B., Russell, A.D. (1983): Pharmaceutical microbiology, 3rd edition, (Blackwell Scientific Publications).

[45] Heijenoort, J. (2001): Formation of the glycan chains in the synthesis of bacterial peptidoglycan, Glycobiology 11: 25-36.

[46] FARKAŠ, V. (2003): Structure and biosynthesis of fungal cell walls: methodological approaches, Folia Microbiologica 48: 469-478. 
Table 1. Minimum inhibitory concentration (MIC) of tested compounds 2a-g

\begin{tabular}{|c|c|c|c|c|c|c|c|c|c|c|}
\hline Microorganisms & 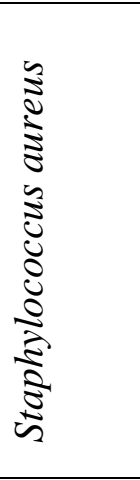 & 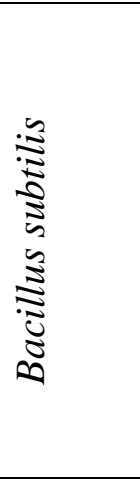 & 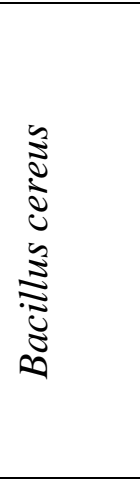 & 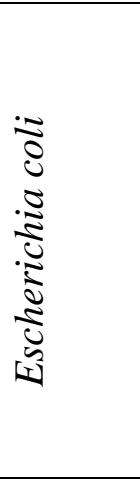 & 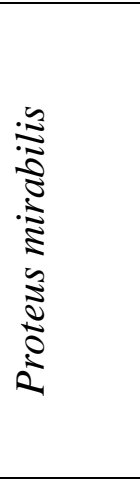 & 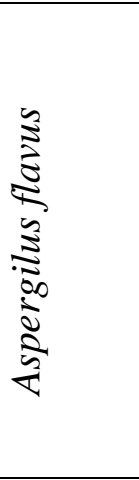 & 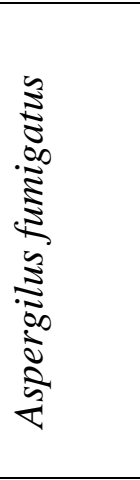 & 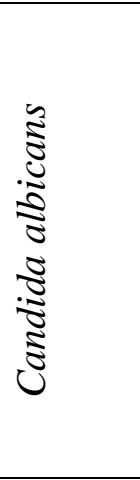 & 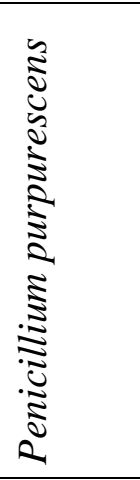 & 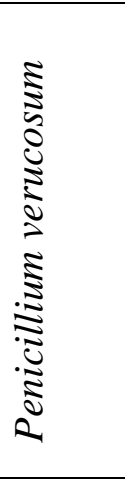 \\
\hline $\mathbf{2 a}$ & 0.156 & 0.009 & 0.019 & 0.312 & 0.156 & 0.625 & 0.312 & 0.312 & 0.312 & 0.625 \\
\hline $2 b$ & 0.625 & 0.078 & 0.156 & 2.5 & 1.25 & 5 & 2.5 & 1.25 & 5 & 5 \\
\hline $2 c$ & 1.25 & 0.156 & 0.312 & 2.5 & 1.25 & 5 & 5 & 1.25 & 5 & 5 \\
\hline $2 d$ & - & 0.625 & 1.25 & - & - & - & - & - & - & - \\
\hline $2 e$ & - & - & - & - & - & - & - & - & - & - \\
\hline $2 f$ & - & - & - & - & - & - & - & - & - & - \\
\hline $2 \mathrm{~g}$ & - & - & - & - & - & - & - & - & - & - \\
\hline Antibiotics & 0.031 & 0.016 & 0.016 & 0.062 & 0.062 & 0.078 & 0.078 & 0.039 & 0.156 & 0.156 \\
\hline
\end{tabular}

Values given as $\mathrm{mg} / \mathrm{mL}$

Antibiotics: Streptomycin (for bacteria) and Ketoconazole (for fungi), 